\title{
HIGH-SKILLED FEMALE IMMIGRANTS: \\ CAREER STRATEGIES AND EXPERIENCES
}

\author{
Saba Colakoglu \\ Georgia Institute of Technology, Atlanta, Georgia, USA \\ Koc University, Istanbul, Turkey \\ Dilek G. Yunlu \\ Northeastern Illinois University, Chicago, Illinois, USA \\ Gamze Arman
}

University of the West of England, Bristol, UK 


\begin{abstract}
The motivation for this study is to uncover career-related issues that high-skilled female immigrants face and their strategies for rebuilding their careers upon migration to a new land. To explore this topic, we performed in-depth interviews with 14 Turkish female immigrants in the U.S. who have successfully rebuilt their careers from scratch upon migration. Content analysis of in-depth interviews with key informants on the subject revealed five theoretical themes that captured the career experiences of these individuals: non-linear career entry, career-orientation, immigrant spirit, social support network, and socialization patterns at work. Integrating these findings with theories on adult learning, we developed a series of theoretical propositions for an experiential learning model of career reconstruction among high-skilled immigrants.
\end{abstract}




\section{High-skilled Female Immigrants: Career Strategies and Experiences}

"I have an immigrant mentality, which is that the job can be taken away at any time, so make sure you earn it every day...immigrants come here they have no safety net-zero. I landed here with $\$ 500$ in my pocket. I had no one here to pay for me." Indra Nooyi, CEO, PepsiCo (Born, raised, and educated in India)

\section{Introduction}

Skilled immigrants - with education, experience, and competence levels on par with corporate expatriates - make up a rapidly growing percentage of the global workforce (Gaillard and Gaillard, 1997; Iredale, 2001; Mahroum, 2000; Purkayastha, 2005; Shachar, 2006) and have started to receive attention from international management scholars only recently (Al Ariss \& Syed, 2011; Al Ariss et al.; 2012; Cerdin et al., 2014; Syed, 2008), with few studies taking a gendered perspective on the subjective experiences, issues, challenges, and career strategies of high-skilled female immigrants (e.g. Iredale, 2005; Myers and Pringle, 2005; Purkayastha, 2005; Ressia et al., 2017; van den Bergh \& Du Plessis, 2012). This is an oversight since highskilled females' labor market transition and entry has been reported to be more difficult compared to their male counterparts (Kofman and Raghuram, 2006; Liversage, 2009; Man, 2004; Purkayastha, 2005). This trend is attributed to a multitude of issues which include the privileging of male-dominated fields in immigration processes (Kontos, 2011; McCoy and Masuch, 2007), discounting of previous work experience and lack of local work experience (George and Chaze, 2009; Meares, 2010), non-transfer of education credentials and accreditation barriers (Purkayastha, 2005; Salaff and Greve, 2003), females' lack of diverse social networks (Salaff and Greve, 2004), possession of dependent visa status (Cooke, 2007; Yeoh and Khoo 1998), and prioritizing of domestic responsibilities (Meares, 2010; Purkayastha, 2005). Consequently, de-skilling and downward occupational mobility seems to 
be the norm for females upon migration based on existing literature (Ressia et al., 2017).

With this backdrop on the challenges faced by high-skilled female immigrants, the aim of this research is to contribute to the literature on skilled migration by exploring their subjective career experiences as they strive to overcome barriers and establish their careers from scratch, while balancing work and private lives with limited or non-existent organizational support. In this qualitative study, we specifically focus on high-skilled females with the assumption that gender plays a unique role and significantly shapes the ways in which immigrants experience and approach their careers (Myers and Pringle, 2005; Yeoh and Willis, 2005). We contribute to the global mobility literature by exploring answers to the following two research questions. First, what are the individual and situational factors that determine career success and positive career experience among high-skilled female immigrants? This question addresses how highskilled immigrants who have been successful post-migration, approach their job search and career building; what kinds of social and psychological support mechanisms they employ; and the unique individual qualities they share to overcome visible and invisible barriers. Two, what is the process through which such individuals successfully rebuild their careers? This question addresses whether there is a career process in place applicable to immigrants in general that can explain those that succeed versus fail in their post-migration career journeys. We explore both research questions inductively via grounded theory (Charmaz, 2006; Edmondson and McManus, 2007; Glaser and Strauss, 1967; Locke, 2001) since we focus on "the actual production of meanings and concepts used by social actors in real settings" (Gephart, 2004, p. 457) - rather than testing specific a priori hypotheses (Martin and Turner, 1986). The grounded theory method was developed to study "fundamental social or social psychological processes within a social setting or a particular experience" (Charmaz, 2006, p.7). It enables 
researchers to capture temporal sequences of the process by its coding method (Charmaz, 2006), focusing on the process instead of the unit (Locke, 2001). In doing so, it can explain the focal social and psychological processes in new theoretical terms, delineate the causes and conditions under which processes emerge, and demonstrate their consequences (Charmaz, 2006; Glaser and Strauss, 1967). Qualitative research is inherently process-oriented, while quantitative research tends to be variable-oriented (Jaccard and Jacoby, 2010; Maxwell, 2004). Therefore, grounded theory as a methodology is appropriate for our purpose of gaining new theoretical insights from immigrants' own narratives. In doing so, we rely on the subjective experiences of individual actors per se and attend to how these subjective experiences can be abstracted into theoretical statements (Suddaby, 2006).

Before we describe our study context and sample characteristics, we start by a comprehensive literature review on the careers of high-skilled immigrants from which our research questions emerged, and provide the definition of high-skilled immigrants that we relied on for selecting our respondents. Our paper concludes by developing a series of theoretical propositions for an emergent experiential learning theory of career reconstruction and discussing its theoretical and practical implications for global mobility.

\section{Research on High-skilled Immigrants}

Former studies on the experiences of skilled immigrants examined a variety of samples who moved, for example, from Lebanon (Al Ariss, 2010) and North African or European countries to France (Cerdin et al., 2014), from several countries to Canada, Spain, and France (Zikic et al., 2010) and Norway (Fossland, 2013), from Sri Lanka to New Zealand (Tharmaseelan et al., 2010), from Southeast Europe to Western Europe (Winterheller and Hirt, 2017), from Poland to Ireland (Pearson et al., 2012), and from India, China, Pakistan, Iran and Bangladesh to Canada 
(George et al., 2012).

Relying primarily on qualitative or mixed research methodologies, these studies examined the specific barriers faced by high-skilled immigrants and the strategies they pursued for coping with the challenges faced upon immigration. In their review of the studies on skilled immigrants, Al Ariss et al. (2012) propose a three-level categorization of contextual barriers faced by immigrants: history, macro-context, and organizational-level. It should be noted that a combination of them, in addition to individual factors, shapes the unique experiences of skilled immigrants in a host country. First, historic relations between countries of origin and destination, and the history of migration, diversity, and racism in the host country determine the legal aspects of immigration, as well as locals' perception of immigrants in a given context.

At the macro level, country-specific legislation and policies regarding immigration and work authorization processes can be listed as the primary issues (Al Ariss et al., 2012), which were emphasized by policy-makers and immigration specialists involved in some studies as part of the study sample (e.g., Al Ariss, 2010). The regulations have direct implications such as lack or low amounts of opportunities for practicing specific occupations (e.g., medical doctors, lawyers), and were defined as the primary reasons for the prevalent underemployment of immigrants, since degrees received from home countries were not recognized in host countries (Fossland, 2013; Winterheller and Hirt, 2017).

Organizational-level policies are also influenced by macro-level legislations since strict laws create legal obstacles and increase avoidance of organizations to hire immigrants (Al Ariss, 2010). Consistently, the strength of support provided by human resources departments for resident and work permits appears as one critical success factor for skilled immigrants' workforce entry (Cerdin et al., 2014). In the organizational context, discrimination against 
certain immigrant groups during selection, such as Turkish immigrants in Germany (Forstenlechner and Al-Waqfi, 2010), were also observed in several studies (Dietz et al., 2015; Fang et al., 2013; Winterheller and Hirt, 2017), and such origin-specific examples of discrimination can also be explained by barriers arising from the historical relations between the home and host countries (Al Ariss et al., 2012).

Cultural and organizational challenges have specific gender-related implications revealed by several studies focusing on the experiences of female immigrants. One critical issue, which made these samples unique, was that a majority of such individuals migrated to a new country to join their husbands or partners (Docquier et al., 2012; Liversage, 2009) resulting in 'love migration' (Aure, 2013). Consequently, female immigrants were more likely to face discrimination during job search (Al Ariss, 2010) since they suffered from not belonging to the 'old boys' network' as a foreign woman (van den Bergh \& Du Plessis, 2012). Thus, female immigrants were more likely to accept underemployment, while struggling with the identity challenges arising from the fear of 'being just a housewife' (Liversage, 2009; Meares, 2010). Even those who obtain jobs matching their qualifications were likely to experience a double earnings penalty due to their gender in conjunction with their immigrant status (Lopez, 2012; Purkayastha, 2005).

Regardless of gender, studies show that the critical challenges faced by high-skilled immigrants include maintaining identity, managing identity, developing new credentials, developing local know-how, building a social network, and evaluating career success, as a consequence of perceived and experienced barriers (Zikic et al., 2010). When facing these challenges, immigrants' motivation to integrate into the new country seems to be a determinant of their effort to develop specific strategies, and this motivation depends on critical factors, such as their motives to migrate from their country-of-origin, degree of met expectations in the host country, 
and organizational integration policies (Cerdin et al., 2014).

The literature also shows that high-skilled immigrants developed different survival strategies while struggling with the aforementioned challenges. For example, studies show that building a social network and putting conscious effort to accumulate cultural and social capital for career self-management, (e.g. learning the local language), significantly helped the job search process of immigrants (Fang et al., 2013; George et al., 2012; Guerrero and Rothstein, 2012; Pearson et al., 2012; Tharmaseelan et al., 2010; Winterheller and Hirt, 2017). Researchers also found that, when other tactics failed, getting a formal education in the host country sometimes served as 'an entry ticket' to the job market (George et al., 2012; Winterheller and Hirt, 2017). Relying on different types of efforts, different career strategies developed by skilled immigrants can be categorized via different perspectives. For example, it was argued that immigrants choose one of three options; (i) maintenance via recognizing and internalizing career barriers, (ii) identifying barriers and putting effort to alter them, or (iii) getting involved in entrepreneurial activities ( $\mathrm{Al}$ Ariss, 2010). Regardless of the categorization, the former literature consistently evidenced excessive levels of effort, dedication, and perseverance to succeed in career entry and progress upon immigration. The literature focusing specifically on self-initiated expatriates (SIEs) revealed very similar findings with regard to barriers, challenges, and strategies (Al Ariss and Crowley-Henry, 2013; Al Ariss and Özbilgin, 2010; Shaffer et al., 2012), and this pattern was observed for female SIEs as well (Myers and Pringle, 2005; Muir et al., 2014).

\section{Definition of High-skilled Immigrants}

Spatial mobility of individuals existed as long as humans did. Nonetheless, global flows of workers have changed over the last 40 years (Pryztula, 2015) along with the classification and definitions of these movements. In this study, we rely on previous studies of skilled migration in 
international management literature (e.g. Al Ariss, 2010; Al Ariss and Syed, 2011, Fossland, 2012; Iredale, 2005) and define high-skilled immigrants as foreign-born and raised individuals who at least hold a bachelor's degree from a foreign institution and who moved to another country with intentions to live in that country for an undefined (i.e. temporary or non-temporary) period of time (Mahraum, 2002; van den Bergh \& Du Plessis, 2012).

While our definition is markedly distinct from corporate expatriates who are sponsored by their employers to work and live in another country for a pre-defined period, it is intentionally broader, overlaps significantly with, and encompasses SIEs who have been narrowly defined in the literature (e.g., Cerdin and Selmer, 2014). Our broad approach to skilled migration is consistent with other researchers (e.g. Al Ariss and Crowley-Henry, 2013; Andresen et al., 2014) who argue that it is not always possible to delineate the theoretical and structural differences between immigrants and self-initiated expatriates primarily because the transition from one category to another tends to be rather fluid. Related, McNulty and Brewster (2017) suggest that the boundaries between different categories should be "flexible enough to address the many obvious overlaps between the various international experience concepts" (p.16).

The definition of high-skilled immigrants is broader because first, it does not dictate who initiates expatriation and why, and focuses on those individuals with intentions to stay in the host country on either a temporary or a non-temporary basis. This is because once the relocation takes place, intentions and decisions change and research suggests that many SIEs do not return home (Dorsch et al., 2012) turning in to high-skilled immigrants eventually. Also for most individuals who relocate to another country, decision to relocate is coupled with ambiguous temporal intentions to stay, often with no definite time frame in mind (Shaffer et al., 2012; Tharenou and Caulfield, 2010). Hence, from a temporal and decision-making perspective, a fluid 
relationship exists between SIEs and high-skilled immigrants.

Further, high-skilled individuals not only move internationally for experiential, adventure, or career- related reasons - the motivational emphasis in SIE research (Al Ariss, 2010; Shaffer et al., 2012; Tharenou and Caulfield, 2010) - but also do so for economic, social, and political reasons associated with pull factors of an attractive host country and/or push factors of a home country in social, political, environmental, or economic disarray (Gaillard and Gaillard, 1997; Mahroum, 2000). Finally, the decision to move can involve more people than just one's self, especially if there are partners, spouses, kids, or families involved which is frequently the case for high-skilled female immigrants (Yeoh and Willis, 2005). For all these reasons combined and for the purpose of our research, we include SIEs in our broad definition of high-skilled immigrants.

In doing so, we strongly echo Al Ariss et al.'s (2012) views that the difference between migrants and SIEs is not clear in the literature despite implicit distinctions between the way the two terms continue to be employed (e.g.; van den Bergh and Du Plessis, 2012). The literature on SIEs often excludes consideration of individuals from developing countries and prescribes to implicit assumptions related to why and how white skilled individuals from developed, Western countries migrate (Al Ariss et al., 2012; Berry and Bell, 2011). While bringing conceptual clarity to this ongoing debate is beyond the scope of this paper, our definition is consistent with existing literature on skilled migration; and we focus on this broad category of global workers because they possess levels of human capital comparable to corporate expatriates and thus, deserve further attention from international management scholars.

\section{The Study Context}

The context in which we investigate the career strategies and experiences of high-skilled 
female immigrants is the U.S. - one of the countries that have attracted the largest number of immigrants from all around the world for centuries, making America the greatest melting pot. Surprisingly, none of the studies we reviewed focused on the experiences of highskilled immigrants to the U.S. - even though with its unique history, size, geography, political institutions, and culture - U.S. continues to be a major but a most challenging destination for such individuals. Pew Research Center estimates the current immigrant population of U.S. to be around $12 \%$ to $15 \%$ - with most public policy, debate, and controversy centering on unauthorized and thus, illegal immigration. According to a 2009 report by the Hamilton Project, however, approximately $30 \%$ of immigrants in the U.S. have bachelor's, master's, or $\mathrm{PhD}$ degrees, with $\mathrm{PhD}$ holding immigrants almost twice the size of U.S. born individuals with doctorates - making high-skilled immigrants a valuable source of talent for global and local firms of all sizes (Greenstone and Looney, 2010). According to a more recent report by Migration Policy Institute, in 2014, the total number of immigrants in the U.S. was 36.7 million with $29 \%$ of these individuals having college degrees or higher. Further, the number of high-skilled immigrants has increased drastically from 3.1 million in 1990 to 10.5 million in 2014. Majority of high-skilled immigrants in the U.S. hail from India (14\%), followed by China (8\%), and the Philippines (8\%), with the rest coming from countries all around the world (Zong \& Batalova, 2016). The main sectors in which these individuals are employed are science, technology, engineering, and math (STEM) fields (Greenstone and Looney, 2010; Kerr, 2013; Kaushal and Fix, 2006). For example, reports reveal that one in every five doctor, one in every five computer specialist, and one in every six people in engineering or science fields in the U.S. are foreign-born (Kaushal and Fix, 2006; Zong and Batalova, 2016). 
Participation of high-skilled immigrants in the workforce brings important benefits to the companies and countries in which they are employed. Previous studies suggest that highskilled immigrants help the economy prosper via increased diversity in skills, which leads to higher productivity and innovation (Greenstone and Looney, 2010; Kaushal and Fix, 2006; Kerr, 2013; Nager and Atkinson, 2015; Zong and Batalova, 2016). Further, immigrant employment in the U.S. helps companies effectively respond to talent shortages especially in STEM areas. Some even argue that U.S. companies cannot remain competitive or survive without the inclusion of high-skilled immigrants in the workforce (Nager and Atkinson, 2015). Other than their contributions to the competitiveness of their employers, in comparison to U.S.born citizens, immigrants also have higher rates in starting new businesses and filing patents (Greenstone and Looney, 2010) - supporting the thesis that high-skilled immigration is primarily a process of brain gain resulting in contributions to the U.S. economy (Kerr, 2013; Mattoo et al., 2008).

Despite the availability of such statistics and reports with public policy implications however, our understanding of the subjective experiences that such immigrants go through is less clear. The aim of our research, within this context, is to better understand the career-building process that female immigrants go through as they overcome a multitude of barriers to provide these gains to local employers and the economy.

\section{Methodology}

Since our research questions deal with exploring individual and situational factors associated with career experiences of high-skilled female immigrants who have been successful in rebuilding their careers, we conducted in-depth, semi-structured interviews with 14 Turkish female immigrants who are gainfully and professionally employed full-time in the U.S. We 
did not include underemployed or unemployed high-skilled immigrants because our research question deals with understanding the experiences and strategies of those who overcame career barriers rather than the experiences of those who did not try or who did not succeed even if they tried. We conducted our interviews within a period of three months. In-depth interviews with information-rich subjects were deemed a useful methodology since we did not have a priori hypotheses to be tested. Rather, we were guided by the two overarching research questions, thus focused on the analysis and interpretation of how these actors constructed meaning out of their subjective career experiences upon migration (Suddaby, 2006). The semi-structured interview guide was jointly developed by the authors based on existing literature on the careers of skilled migrants and evolved throughout the interviews as new themes emerged or seemed important or relevant after initial interviews (Charmaz, 2006). Two of the three authors conducted the interviews using the same guide and with ongoing consultation and feedback after interview sessions. The guide consisted mainly of three sections - experience at the time of immigration, career building process, and future plans with subthemes under each main section. The authors made conscious effort to refrain from leading questions (Kvale, 1983) so the answers reflect respondents' pure subjective experiences and asked probing questions to open up the meaning of these experiences (see Appendix for the semi-structured interview guide). The interviews lasted between 36 to 80 minutes and were audio-recorded with consent from participants and then transcribed for coding and analysis. We sent preliminary questions regarding demographics and factual information before face-to-face meetings both to tailor the interview guide according to each subject's unique situation and to ensure that time with subjects was spent on the deeper exploration of immigration and career issues. 
In selecting participants, we pursued a purposeful sampling strategy through identification and intentional selection of information-rich cases related to the phenomenon of interest (Suri, 2011). Specifically, we used criterion sampling and identified individuals that fit predefined inclusion criteria (Patton, 2005) - i.e. foreign-born females with at least a bachelor's degree from their home countries that have immigrated to the U.S. with temporally ambiguous intentions to stay, who have been living in the U.S. for three years or more, and who are gainfully and professionally employed full-time.

Another purposeful criterion used for recruiting participants was to focus on a single countryof-origin to reduce possible variation due to cultural differences among immigrants themselves. A natural target was to interview immigrants from the authors' country-of-origin - Turkey - a sample that all authors had prolonged engagement with (Lincoln and Guba, 1985). Prolonged engagement helps build rapport and trust and having a common cultural frame of reference facilitates co-construction of meaning and mutual understanding during interviews. Related, conducting interviews in Turkish - with specific instructions to freely switch between Turkish and English which all participants did - would ensure subjects express themselves clearly, freely, and authentically without stumbling upon communication barriers. Finally, this would help privileged access to such individuals (Al Ariss and Syed, 2011). Hence, the respondents were recruited through authors' personal and professional contacts who fit predefined inclusion criteria.

Within the sample of participants, the average age is 41.9 - ranging from 28 to 54 years old. All but three participants are married with kids. Average number of years since initial relocation to the U.S. is 14.3 , ranging from 3 to 27 years. While this may be considered a long time to be recollecting experiences, studies on transitional events in general (Pillemer, 2001) and 
immigration in particular (Schrauf and Rubin; 2001) show that memories associated with life transitions are especially vivid and long lasting. This is because people undergoing major life changes do not have familiar scripts to guide their behaviors and attend closely to specific events occurring in the new environment that contain critical information about how to survive and succeed. The novel events are thought about repeatedly, thereby enhancing their persistence in memory (Pillemer, 2001).

All participants held bachelor's degrees from reputable universities in Turkey with three also having graduate degrees. Prior to their relocation, on average, participants have had 6.3 years of work experience in Turkey ranging from no experience (one participant) to 13 years of professional experience. They were educated in diverse fields ranging from business to law to engineering and medicine and are now employed in diverse industries ranging from energy to higher education to technology and health care. Having unique life, family, and career stories and challenges of their own, the sample provided rich data for exploring the career experiences of female immigrants that possessed high levels of human capital prior to relocation but had to start from scratch upon immigration.

\section{Analysis}

Data analysis in grounded theory involves "the systematic comparison of small units of data (i.e., incidents) and the gradual construction of a system of categories that describe the phenomena being observed" (Langley, 1999, p. 700). Thus, we used an iterative and comparative method to analyze the data generated through in-depth interviews (Glaser and Strauss, 1967; Miles and Huberman, 1994). First, each transcript was read independently by all three researchers for open coding - performing an initial word-by-word examination of the data for developing provisional concepts (Strauss, 1987). We then built upon each other's coding - discussing similarities and 
differences in respective interpretations. Finally, we moved on to axial coding to identify connections and relationships among open codes, and moved onto selective coding to collapse them into five main conceptual themes. Table 1 represents the data structure that reflects the coding of the data.

Table 1 about here

We also switched back and forth between data and theory, comparing the career experiences emerging from our data and evaluated what emerged relative to the existing skilled migrants' careers literature (Strauss and Corbin, 1997). As a result, we started building an experiential learning theory of career reconstruction among high-skilled immigrants that captures the process we identified for how these individuals approach their careers upon migration and incorporates the five conceptual themes that emerged from the data. In what follows, we explain the emerging theory and provide power quotes for the five main theoretical themes. In explaining thematic findings, we give precedence to power quotes because they most strongly and accurately reflect the essence of the theoretical themes that emerged during analysis. Before developing our theory, however, it is important to note the motivation and diverse reasons for why these individuals migrated - validating our specific definition of high-skilled immigrants. The most commonly cited reason for immigration for this group of participants was to follow their spouses' or partners' careers (i.e., love migration), followed by education, and lastly for self-initiated career moves. This is consistent with existing research, which shows that reasons for migration show gender-specific variability such that in comparison to their male counterparts, high-skilled female immigrants are more likely to migrate to a new land as dependents first (Liversage, 2009). 
Despite different reasons to move and relocate, however, the common theme across individuals was that the decision to move either individually or with a spouse was typically given without much systematic deliberation, research, or reflection on the potential long-term social, familial, cultural, and financial trials and tribulations of this significant life change. Similarly, less thought was given to intentions to stay or leave upon a predefined period. As one participant reflected:

"We were completely flexible. We could have turned back, we could have stayed, or we could have moved to another part of the world. It all boiled down to where we could establish a beautiful life together. It wasn't enough for only one of us to be successful. We had to live in a country or a city where both of us could be happy."

\section{Findings}

A critical component of the overarching research questions for this study is the 'experiences' that individuals go through post-migration and how they make sense of those experiences along with the factors that shape and influence those experiences. Upon analysis of our interview data, we noticed that experiences - in the context of migration and career building - can also be construed as unique opportunities that individuals can reflect upon and learn from. This notion is in line with adult learning theories that emphasize a person's transaction with his or her social environment as the most important conduit through which learning takes place (Kolb, 1984; Piaget, 1977). In his influential work on adult learning, Kolb (1984) describes a dynamic adult learning process that starts with a concrete experience that is novel, salient, and stimulating, which then becomes the basis for reflective observations, abstract conceptualizations, and ultimately active experimentation. Through this process, new ideas are formed, tested, rejected, or validated - which then result in changes in a person's repertoire of knowledge and thus, represent internalized learning (Weiss, 1990). With this new insight, we began to build on 
Kolb's (1984) adult learning theory and integrate it with thematic findings from this study to develop an experiential learning model of career reconstruction among high-skilled immigrants. We propose that those individuals who successfully go through the different stages of the cycle and are intentional about all of its components are more likely to rebuild their careers in the host country than those who do not engage themselves fully and openly in all of these stages. The list of propositions derived from integrating thematic findings with adult learning theories are stated in Table 2.

Table-2

\section{An Experiential Learning Model of Career Reconstruction among High-skilled Immigrants}

The adult learning theory developed by Kolb (1984) suggests that the learning process that improves one's effectiveness when facing challenges follows a four-stage, continuously

recurring cycle. It starts with a 1) concrete experience followed by 2) observation and reflection, which lead to 3) the formation of abstract concepts and generalizations, which then lead to 4) hypotheses to be tested in future action, which in turn become new concrete experiences. Kolb's theory also suggests that learning is governed by one's felt needs and objectives and that learning becomes inefficient when personal objectives are not clear (Kolb et al., 2000).

Accordingly, adults are often motivated to learn due to a problem, issue, or challenge they face personally or professionally. One salient problem that motivates high-skilled female immigrants - based on findings from this study and previous literature - is the status collapse they experience in their careers upon migrating to a new land (Chiswick et al., 2005; Fossland, 2012; Liversage, 2009; Ramboarison-Lalao et al., 2012). Our results show that those immigrants who perceive a status collapse to be problematic to their self-concept proactively set the learning cycle in 
motion. Accordingly, these individuals are all highly career-oriented (conceptual theme 1) and their careers are an important part of their core self-identity. Hence, this disposition urges them to take action and set the learning cycle in motion.

\section{Career-orientation}

Our results revealed that for the individuals in our sample, not working, not being productive, or not putting their education, experience, and expertise to good use was not considered a viable option in life. While they realized, sooner or later that career goals in line with self-imposed expectations would not be fulfilled overnight, they were willing to work hard and make sacrifices to make that happen. For many, the value of work and a vision for the ideal sequence of events in life have been conditioned since childhood and that meant staying at home with or without children could damage one's self-worth and purpose in life, leading to identity crisis. For those with young children during transition, only being a 'mother' was not sufficient for life satisfaction. Only after proving their worth in the work place and putting their careers back on track, they tended to intentionally lean back to maintain a certain degree of work-life balance. That is, most participants also viewed their career experiences in the wider context of both professional and family responsibilities. As one participant noted:

“...careers, especially in Turkey, your life is already planned ahead of you. You'll finish school, you'll take the exams to get in the best schools for middle school, then high school, and college etc. All your life is built upon having a good career and being successful. Of course later on, I wasn't dreaming or anything, but you need to get married, have kids, things like having a happy life..."

Another participant, upon reflecting on her dad's impact on her approach to life and careers noted:

"Father used to talk such that you have to work. Ok you have kids and took care of them for a while but doing that for the rest of your life is not an option. He pondered, why did you study 
then?"

Another participant reflected on her first two years of not working and taking care of a young child:

"It was hard - waking up and not going to work, it felt like I lost my identity. My occupation is extremely important for me and I've lived all my life with the urge to have an occupation and suddenly it's all gone, my job, my occupation. I knew this would happen but I ended up being a typical housewife who cooks all day. After that much investment in education, I couldn't accept it and was unhappy. Of course certain individuals might prefer this but everyone has their priorities. My priority is my job... Of course having a family is important and your kids come before all else but I questioned whether this was a good decision or not..." Although status loss is a common experience for migrants in general (Aycan and Berry, 1996), we argue that those individuals whose core self-identities are anchored on their careers will actively set the learning cycle in motion. Hence, we propose the following:

Proposition 1: High-skilled immigrants with higher levels of career-orientation are more likely to set the learning cycle in motion and immerse themselves in concrete experiences in job search and career-building.

Once the learning cycle starts circling, individuals go through concrete experiences and in the context of this study, concrete experiences correspond to all the actions individuals proactively pursue to identify employment opportunities upon migration, when personal objectives regarding the desire to work, be productive, and regain status is clearly felt. Such concrete experiences early in the career building process include actively looking for work and applying for jobs, going to interviews, reaching out to contacts, getting advice from mentors, underemployment, volunteer work and the like. That is, most of the early concrete experiences take high-skilled immigrants towards a non-linear path to eventual employment and career entry (conceptual theme 2).

\section{Non-linear career entry}


After leaving Turkey with full-time and gainful employment and promising careers, all participants but one (who had an intracompany transfer with a local contract) stalled in their career tracks for a while to take a voluntary or involuntary break, go to school,, or to work in low-paid or voluntary jobs. The career journeys of participants typically started by early work experiences - or sometimes temporary gigs - for which they were typically overqualified. Hence, underemployment upon initial entry in the labor market was the norm; expected and accepted. Compared to where they left off their careers back in Turkey, they either had to start from scratch or start in fields unrelated to their primary areas of expertise. Even for those who found employment in their respective areas of expertise, they typically had to start in entrylevel or junior positions that were steps back from their respective career stages. As a result of this non-linear career progression and eventual labor market entry, a temporal transition penalty was paid due to additional time spent on finding, getting, and establishing an early work history. Additional transition penalty was paid due to underutilization of one's education, experience, and skillset and lost or reduced income due to underutilization. This finding also supports Mattoo et al.'s (2008) findings that in comparison to those from Asia and industrial countries, educated immigrants from Latin America and Eastern Europe usually find jobs they are overqualified for after a long job search and typically experience underutilization of their skills.

Proposition 2: Early career-related concrete experiences of high-skilled immigrants are characterized by a non-linear path and periods of excessive job search, unemployment, and underemployment.

Further exploration of the early career experiences and the non-linear path which defines this stage revealed another key characteristic that all the participants shared in common. Somewhat related to their career-orientation and manifest in their approaches to job search and beyond, 
the respondents shared personal characteristics that gave them the push and drive to actively pursue their careers despite structural, cultural, and social constraints which we named as the immigrant spirit (conceptual theme 3).

\section{Immigrant Spirit}

Immigrant spirit includes characteristics that include hard work, patience, persistence, not giving up, achievement-orientation, and a strong will and commitment to succeed. These qualifications can also be accurately summarized in what Duckworth (2016) refers to as grit and what Chua and Rubenfield (2014) in explaining the relative success of certain minority groups in the U.S. refers to as impulse control. Accordingly, grit refers to perseverance and passion in the achievement of long-term goals, and impulse control refers to self-discipline, self-control and the ability to resist temptation. Most of these characteristics were evident in how participants explained themselves:

"My personality is that I don't give up easily... I do my best to learn quickly by putting extra effort, by asking, trying. Naysayers didn't think it was possible to make it as a doctor in the U.S. They said other friends who were doctors in Turkey couldn't make it. I selectively listen to other people's input but I choose my own path, I want to try and see for myself, that's my character. I knew it would be difficult so I didn't get upset."

"It's about my stubborn character. My first one and a half years here were very hard. I could have gone back I didn't have a contract but then I questioned how come many people achieve this and I can't... If I returned, that would be a failure for me and would have made me very uncomfortable. I asked myself whether I've tried hard enough before making a decision - I decided that I had to make the best out of this bad situation and things improved after that, I changed my department, got promoted etc. Three and a half years passed but I did that questioning a lot - if I went back to Turkey that would have been a failure that I couldn't accept. I would feel defeated - it was about me being extremely ambitious." 
In summary, while we already proposed that those high-skilled female immigrants that set the adult learning cycle in motion are highly career-oriented, those that keep on turning the wheel are the ones that display an immigrant spirit with a strong will and dedication to achieve longterm goals.

Proposition 3: High-skilled immigrants that keep on turning the learning cycle display immigrant spirit qualities such as grit (Duckworth, 2016) and impulse control (Chua and Rubenfield, 2014).

Reflective observation and abstract conceptualization of concrete experiences are the passive stages that one needs to go through introspectively for effective and personalized learning to take place. Reflective observation focuses on trying to understand concrete experiences objectively by reflecting upon their meaning. Abstract conceptualization emphasizes the use of logic, ideas, and concepts developed as a result of reflection and introspection. During these relatively passive stages of the learning cycle, the focus is on logical reasoning and formation of generalizations, guidelines, and personal theories regarding the problem at hand. For example, as our data shows, most of the early experiences are characterized by multiple challenges, hurdles, rejections, and failures accompanied by a blow to one's self-concept, worth, and esteem. Most respondents thought carefully about the meaning of these early concrete experiences and tried hard to see and understand their implications for moving beyond the initial despair they experienced. Indeed, this stage requires patience, impartiality, and thoughtful judgment (Osland et al., 2007). For example, a participant who worked multiple jobs to make ends meet reflected on the existential or spiritual contributions of these early experiences:

"The contribution is that your understanding of life expands. Was it supposed to be that hard? I still would have learned if I experienced half the hardship. People become slaves to their lifestyles and assets. I understood none of it matters - everything comes and goes. I come from 
a good family, somewhat wealthy, I've been to America and all, and realized I grew up in a bubble of educated and wealthy people.... I've met many interesting lives and people outside of my bubble that I've matured spiritually. Not necessarily career-wise but in the form of maturity and fortitude."

Another participant reflected on the important lessons learned from early job experiences even though these were jobs with very little or no income and no fringe benefits.

"Looking back, I am very glad - that I learned about work ethics. I even almost got laid off from the library during budget cuts but they were also evaluating our performance. How many books we place, number of complaints from your department etc. Every few months we received feedback. The supervisor would come and talk to you. Formal interview, formal feedback. I even managed to stay after the layoff period and my husband was teasing me that I survived my first layoff in America. When working at the day care center, there were lots of formal meetings. I learned a lot during those meetings among teachers, how to conduct business, how to develop relations. On top of that, I used them as character references while entering the medical field and also when starting my residency. I think these were all very useful."

Upon reflective observation, many high-skilled immigrants in this sample arrived at abstract conclusions or personal theories such as "home country credentials do not count as they did back home" and that "building local credentials - education or experience - is the key to a successful career journey". Others realized that to be successful in finding opportunities "support from mentors, family, or influential people" matter. These are examples of abstract concepts that were developed through reflective observation and served as the basis for active experimentation.

Proposition 4: High-skilled immigrants who objectively and intentionally try to understand concrete experiences drive lessons learned that they use for active experimentation. 
Finally, active experimentation stage focuses on putting the newly formed generalizations into practice to assess their validity in real life. It requires proactively trying and testing ideas to influence people and change situations. Active experimentation is a pragmatic stage that deals with what works and what doesn't with a focus on doing and action - as opposed to observing (Kolb, 1984). Active experimentation sets the learning cycle back into motion by creating new concrete experiences. In the context of this study, active experimentation is about modifying career strategy, changing behaviors, or trying new approaches to accomplish career outcomes and creating new concrete experiences that one can further learn from.

For example, one of the frequently cited barriers to workforce entry is immigration status and lack of work permit leading to difficulties finding sponsor employers. U.S. immigration laws are complicated depending on one's unique situation and there are various types of visas that allow an individual to work legally in the U.S. - the most common categories being permanent residency (i.e. Greencard), H- 1B visa (temporary work permit for professionals), and student visa allowing for part-time work on college campuses. Second, even for those with the required immigration status, lack of local education and experience credentials was a major challenge when looking for jobs. As a result of realizing the significance of structural barriers that prevent them from participating in the labor market, all participants actively experimented with pursuing, starting, or getting local education credentials. As one participant noted: "Actually I went to a lot of interviews but you need to have work experience here. I had 1-2 years of experience in Turkey but they don't know the value of your education from Turkey. In Turkey, it's got a name, it's prestigious but when you come here, because they don't know it, you become nobody." Further, many cite language barriers, having an accent, or not being fluent enough as other significant hurdles they realized prevented them from landing on career opportunities. Related, 
participants had an acute awareness of the shortcomings and liabilities of being an immigrant and in line with their driven characters, actively and creatively experimented with different methods to overcome such shortcomings. Most frequently cited shortcoming was lack of conversational fluency and having an accent. One participant noted:

“There's an accent reduction program at the state university - for real - they look for people with clinical and physical disabilities or they accept Chinese or Indian. I asked them whether they would accept me, and they sent me away. But then I had one-on-one training sessions with a student. I thought if I want to enter the communications field, I need to do this - the waiter has difficulty understanding when I give an order. It's very interesting: they give you written, oral, and listening tests - of course I aced my TOEFL with a full score and all but having an accent is different. I did the test and they congratulated me on having an American English at the level of a 13-year old. I couldn't believe but they said it was normal for a foreigner. Imagine all the Turkish you learned between 13 to 30 years of age is wiped away all of a sudden. I thought this is terrible because people you'd meet would have no clue how smart you are because you talk like a 13-year old. We worked but the program had little impact so I started watching old nonsense shows that Americans grew up with to understand how their minds work."

Another participant actively experimented with similar strategies:

"Except for yes, no, hi, how are you I had no English when I first came here because my focus was German .... I tried hard to improve myself. Also, and I'd advise to everybody, I watched TV with the caption on. I didn't listen to any Turkish music in the car. I learned how to write from the captions and how to speak from radio communication."

Proposition 5: High-skilled immigrants that eventually become successful actively and creatively experiment with different tactics to overcome barriers and shortcomings.

Another interesting finding from the data was that most individuals - typically after an intense period of actively seeking, pursuing, and asking for opportunities through formal and informal channels and actively experimenting with different tactics to overcome shortcomings and 
barriers - landed on their first meaningful career opportunities due to a powerful Turkish connection or through other important, influential contacts they had somehow access to. The rest mentioned specific hiring managers who were 'sympathetic' to foreigners or who had an interest in international affairs and attributed their big break to 'getting lucky'. In summary, active experimentation stage was characterized by the realization of the importance of social connections and a support network that helped the immigrants with their struggles (conceptual theme 4).

\section{Social support network}

Experiences of respondents reflected the advantages and the importance of having a support network in rebuilding careers. Given lack of organizational support for this group of international employees, the support network seemed to be of critical value for the majority of respondents. The potential network consisted of three main actors and all participants benefited from the presence of at least one of them.

Spousal support appeared to be the most important career enabler for the married female immigrants in this sample. Spouses provided emotional support as well as professional guidance. Their specific suggestions, feedback, and critiques during participants' efforts for career entry constituted key advice for several participants and were clearly articulated in the interviews. One participant reflected on the contribution of her husband during active experimentation stage as follows:

"My husband was very supportive, both emotionally and logistically. What I mean by logistically is that - there was a course I used to attend (to improve her chances in the job market) and I wasn't driving, back then. He was driving me there every weekend and was waiting for me until the end of it, 4 or 8 hours, or so. My career success had a lot to do with his efforts to help me." 
Powerful home country contacts and sometimes mentors residing in the U.S. also had a critical impact on the progress of several participants during active experimentation. These individuals supported high-skilled immigrants by providing cross- cultural adjustment guidance as well as career strategies specific to the U.S. They helped with major career decisions, such as the dilemma of pursuing academic or professional career paths. In few cases, mentors served as key people who prevented participants from giving up and returning to Turkey after unsuccessful attempts at labor market entry. Participants who did not have a chance to find such mentors felt lack of such support. One participant, who felt very lucky to have a powerful Turkish mentor, specifically explained how her need for a Turkish mentor led her to join the Turkish-American alliance in her city. She later emphasized the importance of having a mentor:

"Anytime there was a new issue - an interview, an obstacle, etc. - I used to call her. She was very supportive and always gave me excellent advice, which led to good results, thanks to her approach and perspective. Therefore, she is very important to me."

Last but not least, financial or emotional support of families - either in the U.S. or Turkeyplayed a significant role during the active experimentation stage. In addition to psychological support, families helped participants financially by, for example, giving money during times of unemployment, buying a car since it was needed due to the location of the organization, and even helping with preparation of CVs and cover letters. Despite efforts of families in Turkey, not having a family in the U.S. was felt in several important ways, and influenced the career decisions of some participants with children.

Proposition 6: High-skilled immigrants' social support network and connections gain prominence during the active experimentation stage in the learning cycle. 


\section{Learning cycle keeps on turning...}

The nature of the learning cycle is recurring such that as long as individuals are motivated to learn and find solutions to personal and professional issues they face, the learning cycle keeps on turning. The recurring nature of the cycle is also evident in the way that individuals move through different stages of the cycle and engage in active experimentation as the last stage that becomes new concrete experiences to reflect upon and conceptualize on. Over time, however, the content of learning shifts to the new professional and personal issues at hand. Our data shows that after getting their initial break and putting their careers back on track - most participants cite fast and frequent promotions or landing on better jobs in a relatively short period of time - the career progression of the participants became more linear, selective, and intentional. Related, the learning cycle shifts its focus to understanding the cultural, social, and political space that high-skilled immigrants are embedded in to continue their professional and personal development. Hence, observations, reflections, conceptualizations, and active experimentations emphasize learning of tacit socialization patterns in the workplace (conceptual theme 5).

Proposition 7: Learning cycle of high-skilled immigrants' post-career entry emphasize understanding and learning socialization patterns in the workplace.

\section{Socialization at work}

Interviews revealed mixed but interesting findings about patterns of socialization for highskilled female immigrants after putting their careers back on track. First, even though they found themselves to be competent in technical and functional knowledge and skills - especially after complementary local education and experience - they realized the importance of sensing and understanding the socio-cultural space, cultural nuances, pop culture, and sports in social contexts and for building professional relations. Consequently, they felt less adept in situations 
that required social interactions. For example, one referring back to an earlier work experience commented:

"I knew how to do my job. I had no problems with work meetings about projects. However, I really didn't like attending social events with colleagues. I didn't know what to talk about. They would talk about baseball or other things I didn't understand. It made me feel very uncomfortable. I preferred socializing with people from Spain or Germany. In my company, I was the only foreigner. There was a girl from Puerto Rico. I felt as if I was the minority of a minority."

Delving into cultural differences during the adjustment and socialization process, another participant indicated:

"I was fine with technical abilities. But, my biggest challenge was cultural content, especially in advertising. We would go out with my colleagues and I couldn't follow the conversation at the deepest level because I didn't know the pop culture. I didn't grow up with it. I could understand perhaps $10 \%$ to $30 \%$ of the content."

Surprisingly, at this stage - unlike the earlier stages in the job search process - some perceived having an accent or a strange name as an asset, a conversation starter rather than a challenge in social contexts.

"My boss told me that people paid more attention to me due to my accent, and this was an advantage. Having a strange name people remember you more. Plus, I think I have to think very carefully about my selection of words. Perhaps this helps as well."

Another participant echoed the feeling:

"I feel being a foreigner and having an accent attracts people's attention. They listen to you very carefully. They ask questions about your home country, they want to learn more about you. It creates a starting point."

Related, some participants found it difficult to connect with American colleagues and tended to lean towards other international colleagues to socialize at work:

"I get along well with Latinos, Italians, Spaniards. Mediterranean culture. We are more 
direct and more open. We operate with our emotions. Our foods and tastes are similar. I have to try harder to find common points with my American colleagues."

Social attraction towards internationals was either natural due to common shared experiences and mindsets, or due to failed attempts to socialize with Americans resulting from cultural differences in expectations for the nature and frequency of socialization at work.

"For example I organize a lunch outing, no one shows up, only a few - only the Turks or those who want to have lunch out. They don't have the sense that they can socialize with people at work, private life is of utmost importance. They don't like to go out of their work zone, we are much more connected. At first I was puzzled, I was putting effort, trying to get closer but they don't reciprocate. I wondered if there was something wrong with me, I try hard to build trust with no outcome so I gave up. I understood it wasn't about me. They're like that among themselves too. That's why I accepted it the way it is, I can't change it."

Finally, participants' socialization at work also seemed to bifurcate along the lines of age and marital status. Younger and single immigrants tended to be more social at work establishing stronger personal relationships, whereas married and older immigrants had less time and/or need for socialization at work. One of the young and single immigrants noted: "All my friends in Chicago are the friends I've made at my first job. Two of them are my best friends. I see them often. One of them, I see her 24/7. We go out together; we do a lot of activities. We have even gone to vacation together."

Another young, recently married with no children, participant shared:

"My current place hires people based on their personality, second only to their technical skills. If they have less experience, but have the right personality, we hire that candidate. We can teach them the skills, but not the right personality for our work environment. We spend a lot of time together as a team. On Fridays, we drink beer at work; cases of beer are brought in. We often go to happy hour after work, and we even have breakfast together. Even if we don't have a social event at work, I usually hang out with someone from work when I leave the office. I 
have very close friends, I have even stayed at some of my work friends' home."

However, older married females with kids at home were less likely to socialize at work. One of the participants indicated:

"I have a good friend at work. I don't socialize with her outside of work. I have lunch with her almost everyday. But, I don't see her outside of the work environment. I have a few other friends. But, we do not socialize much, although the work environment is fun and nice."

Finally, when participants were probed regarding perceptions of a glass ceiling due to being an immigrant and/or a female, none perceived being an immigrant to be a barrier to further advancement and all perceived their gender to be the primary culprit for limited advancement opportunities beyond mid-management. One participant who had experience with multiple firms noted:

"Unfortunately glass ceiling is everywhere. Sometimes when I look at Turkey, looking at newspapers and such I think women tend to advance more there. Of course they're getting their relatives' support, support from their parents as far as I can tell. From what I see, here you need to belong to the social click among men. In all companies I worked for, of course we are wined and dined with our peers and seniors and there is a personal connection but when it comes to advancement, men advance more easily than women."

Another participant stated:

"Networking is very important in a big corporation. I came from a smaller organization into a campus with 1000 people - you have to make sure you've got good relations. As a single woman, all the people who can help you out are men. That's why I hesitate - networking, coaching, mentoring. There might be misunderstandings. When you're a male you can talk baseball, American football, which I know nothing about. It would have been better if there were more women. So I try to prove myself with my work and it's acknowledged to a certain point but 
when the decision boils down to deciding between two people, they tend to favor males and that's where I lose."

\section{Discussion}

Immigration to another country, no matter what the reason or motivation is, represents a 'vital conjuncture' in life that anthropologist Johnson-Hanks (2002) defines as 'a socially structured zone of possibility that emerges around specific periods of potential transformation in a life' ( $p$. 871). Within this transformational period, the scarce literature on high-skilled female immigration points mainly to the hardships that high-skilled females face in finding employment, compared to their high-skilled male counterparts (Donato et al., 2006). Several gender-specific reasons exist for this trend, which were also manifest in the narratives of our sample. Most importantly, compared to their male counterparts, females immigrate primarily for non-work reasons to follow a spouse or a partner - which Aure (2013) refers to as love migration - and thus face greater barriers in finding work with limited local education and experience credentials and difficult to overcome visa issues (Kofman and Raghuram 2006; Killian and Manohar, 2016; Liversage 2009). Following a spouse was the most frequently cited reason for migration among our participants as well. Second, the gendered division of labor at home where the male continues to be the primary breadwinner with females holding major responsibility for domestic work and childcare - a difficult task when women have lost their former social networks (Salaff and Greve, 2004, 2006) - leads most women to settle for the domestic path when chances of finding suitable employment are grim. For those who do not accept to settle, like the ones in our sample, domestic and childcare responsibilities create an additional hurdle to manage and overcome that their males counterparts typically do not face. Within this gender-specific background and context, we were interested in capturing the 
experiences and characteristics of those females that successfully rebuilt their careers from scratch. This is an under-researched population within global mobility research and “...skilled immigration is an area where women's career experiences remains, up to a certain point, hidden." (Al Ariss and Crowley-Henry, 2013)

Shedding light on this under-researched population, our findings reveal a grounded theory of experiential learning for career reconstruction upon migration leading to seven propositions linking the adult learning process to the five main themes that capture immigrants' career experiences. Gender is a boundary condition for the model and gender-specific concepts are embedded in the model and evident in first-order concepts that were revealed upon open coding. To recap, our study revealed that most females had a non-linear entry in the job market, first going through a period of occupational status collapse, which gave them the initial motivation to activate the learning cycle. While previous studies on the career development of skilled migrants similarly reported on the status drop immediately after migration, talent waste, and downward career mobility (Chiswick et al., 2005; Fossland, 2012; Ressia et al., 2017; Liversage, 2009), we theoretically construed this status collapse as the primary push that drives skilled immigrants, triggering the experiential learning cycle. Perceptions of status collapse that trigger the learning cycle is especially salient and problematic among career-oriented immigrants whose core self-identities are strongly tied to their careers. These individuals also reflect upon and derive important career lessons learned from early concrete experiences during periods of intense job search, unemployment, underemployment, or voluntary work. Our experiential learning theory also suggests that those that continue to actively experiment with new tactics and strategies despite many rejections and failures possess an immigrant spirit defined in gritty qualities such as patience, persistence, and hard work. The contributions of a 
social support network - specifically that of spouses, extended families, and influential contacts - was another main theme that significantly helped respondents' progress with career goals during active experimentation. Without support from spouses and families for example, the gendered division of labor at home where the female's career is secondary to the male would have made it much difficult for these women to have rebuilt their careers. Van den Berg and Du Plessis (2012) also show among skilled female immigrants in Netherlands that feeling rooted and having strong support from parents, friends and family helps female immigrants shape their careers and feel confident in their abilities. Finally, once they secured access to high-skilled labor markets, respondents' biggest challenges related to differences in cultural understandings and lack of cultural fluency, typically leading to issues with socialization and relationship-building in the workplace. However, none cited those to be impediments to further advancement to higher positions or expressed a victim mindset. Rather, they attributed difficulty in advancement to the existence of a gender-based glass ceiling regardless of national origin.

While revealing insights specific to this study, our results also reinforce findings from other studies of high-skilled migration in general (e.g. Ariss and Ozbilgin, 2010; Tharmaseelan et al., 2010) and high-skilled female immigrants in particular (Liversage, 2009; Van den Bergh and Du Plessis, 2012; Meares, 2010). For example, Tharmaseelan et al. (2010), in their positivist exploration of 210 migrants from Sri Lanka to New Zealand showed that in general, immigrants' occupational status declined markedly upon migration. However, immigrants' human capital, social integration and career self-management all contributed substantially to explaining objective career success. Related, Van den Berg and Du Plessis (2012) also found that individual drivers such as identity, social support and life phase play 
a role in women's pre-migration and post-migration career success or exits in the Netherlands. Similarly, Winterheller and Hirt (2017) reported that building up countryspecific work-related social contacts and gaining work experience in local companies were the key elements in the adjustment process and rebuilding career capital for skilled female immigrants in Western Europe. In summary, there seems to be a general trend in the progression and success of skillful immigrants regardless of gender, host country, or home country. Our study contributes to the existing literature by revealing a novel theoretical perspective and developing an experiential learning model for career reconstruction among high-skilled female immigrants. The model construes the whole post-migration process as an adult learning experience and posits that those females who are successful in rebuilding their careers are the ones that engage themselves intentionally, fully, and openly in all stages of the learning cycle. Since the labor market transition process for females is characterized by de-skilling (Man, 2004), feminization (Ho, 2006), re-domestication (Yeoh and Willis, 2005), and compromised careers (Suto, 2009), the model provides theoretical and pragmatic insight for female immigrants on how to more effectively manage the transition process and the factors that determine ultimate career outcomes.

From a practical standpoint, larger employers that rely on a critical mass of high-skilled immigrants and high-skilled females that are considering such moves or those that are already struggling career-wise due to such moves can benefit from the findings of our study. Further, smaller employers with limited resources can also support high-skilled immigrants in ad-hoc ways based on the following practical suggestions.

First, local employers should ensure that their recruitment and selection processes are free of implicit and explicit bias against individuals who were raised and educated in other countries. 
While U.S. employers are already prohibited from discriminating against individuals on the basis of national origin, the uncertainty and the ambiguity of their cultural, educational, and professional background in the eyes of decision-makers leave such capable individuals out of the labor market leading to brain waste and untapped human capital. In a hypercompetitive environment where human capital is one of organizations' greatest assets, it is important that companies tap into the diverse backgrounds and perspectives and the drive that high-skilled immigrants bring to the workplace. Our study also revealed social and cultural challenges that females experience after they start working despite feeling and being confident technically at their jobs. To fully tap into the potential of high-skilled immigrants, during the onboarding and socializing process, employers can provide them with formal or informal home country cultural mentors or buddies who can help them navigate the amorphous social and cultural landscape of the workplace. Especially for females who tend to be more relationship-oriented in their careers, the value of such cultural support and friendship will be invaluable. This is important because women tend to face difficulties in finding mentors in male-dominated workplaces and also experience gender-specific professional challenges in finding mentors due to sex role differences (McDonald and Westphal, 2013) even though mentoring has positive career outcomes for mentees in general (Ragins and Kram, 2007). Finally, while these individuals are hired locally on local contracts, providing support practices similar to those provided to corporate expatriates are easy and cost-effective to implement without creating undue hardship on employers (Caligiuri and Colakoglu, 2007). Unfortunately, anecdotal accounts of immigrants suggest that many employers and managers have difficulty putting these suggestions to practice due to tactical and operational difficulties or implicit biases. Further, this untapped talent pool is often neglected by both local HR departments and 
policy makers in host countries (Iredale, 2005). This can be partially attributed to local managers' mindset who might find it hard to relate to or show appreciation for the experiences and the sacrifices of these individuals with whom they have no firsthand knowledge of or interactions. This is why in any diversity training program, national origin, cultural differences, or immigration experiences should be emphasized to minimize the impact of implicit bias against high-skilled immigrants.

One of our main thematic findings relates to high-skilled female immigrants' non-linear career entry - suggesting that it is extremely difficult for such individuals to break the invisible and visible barriers they face as they try to rejoin the workforce even if earlier barriers such as an accent or a different name become a positive novelty later in some immigrants' careers. Diversity training that includes immigrants as a minority category can thus ease the transition process of immigrants and consequently prevent brain waste because transition is the most difficult part of the whole career experience according to our results. This is especially true for recruitment and selection processes where hiring managers' implicit bias might act against the consideration and hiring of such individuals and with diversity training, they may have a more bias-free cognitive process when evaluating immigrants as candidates.

Like any other study, our study is not without its limitations due to the modest sample size and the generalizability of its findings to other host and home countries. While we conducted our interviews with information-rich cases to gain greater insight, future research can replicate and extend on the findings using a greater number of high-skilled female immigrants from a diverse range of home and host countries or using a priori hypothesis testing on large samples (e.g., Guerro and Rothstein, 2012; Tharmaseelan et al., 2010). For example, how are the career 
experiences of females migrating from developed economies to developing ones (e.g., West to East) different than those migrating from developing economies to developed ones (e.g., East to West); do they face the same levels of hardships or do they encounter different barriers as they rebuild their careers? These questions can further be explored and tested in larger-scale studies.

There is also need for further research to better capture the experiences of female immigrants who migrated for different reasons (e.g., love versus career), who hold different kinds of occupations, and those with different marital status and varying child care responsibilities. For instance, a comparison between high-skilled, middle-skilled, and lowskilled female immigrants could allow to evaluate the role of skill level in migrants' professional success or failure; or exploring the career experiences of high-skilled female immigrants from different regions of the world could unleash any culture-based differences in such experiences.

Finally, by design, this study was an exploration of female immigrants that were striving and succeeding upon migration (Pearson et al., 2011) and the experiential model was developed based on insight gained from this sample. However, skilled migrants go through and construe their careers in different patterns (e.g., Muir et al., 2014) and it would be interesting to compare the experiences of those that are satisficing and struggling (Pearson et al., 2011) to test the validity of the theoretical model in a different group of migrants that construed their careers in different ways. For example, it is possible that those that satisfice or struggle (Pearson et al., 2011) or reversers and rejecters (Muir et al., 2014) get stuck in one of the stages of the cycle, skip certain stages, or overemphasize some of them? It is also possible that they do not even initiate the cycle in the first place? These are all different research questions that deserve 
attention and thus, we invite further contributions to the area of high-skilled female migration. In conclusion, through a thematic analysis of in-depth interviews with information-rich cases and construing career rebuilding as an experiential learning process, we presented new knowledge and theoretical insight regarding the careers of an understudied group of immigrants who are valuable contributors to their teams, employers, and the economy. 


\section{References}

Al Ariss, A. (2010), "Modes of engagement: Migration, self-initiated expatriation, and career development", Career Development International, Vol. 15 No.4, pp. 338-358.

Al Ariss, A. and Syed J. (2011), "Capital mobilization of skilled migrants: A relational perspective", British Journal of Management, Vol. 22 No. 2, pp. 286-304.

Al Ariss, A. and Crowley-Henry, M. (2013), "Self-initiated expatriation and migration in the management literature: Present theorizations and future research directions", Career Development International, Vol. 18 No. 1, pp. 78-96.

Al Ariss, A., Koall, I., Özbilgin, M. and Suutari, V. (2012), "Careers of skilled migrants: Towards a theoretical and methodological expansion", Journal of Management Development, Vol. 31 No. 2, pp. 92-101.

Al Ariss, A. and Özbilgin, M. (2010), "Understanding self-initiated expatriates: Career experiences of Lebanese self-initiated expatriates in France", Thunderbird International Business Review, Vol. 52 No. 4, pp. 275-285.

Al-Waqfi, M. and Forstenlechner, I. (2010), "Stereotyping of citizens in an expatriate-dominated labour market: Implications for workforce localisation policy", Employee Relations, Vol. 32 No. 4, pp. 364-381.

Andresen, M., Bergdolt, F., Margenfeld, J., \& Dickmann, M. (2014), “Addressing international mobility confusion - developing definitions and differentiations for self-initiated and assigned expatriates as well as migrants", The International Journal of Human Resource Management, Vol. 25 No. 16, pp. 2295-2318.

Aure, M. (2013), "Highly skilled dependent migrants entering the labour market: Gender and place in skill transfer", Geoforum, Vol.45, pp.275-284

Aycan, Z. and Berry, J.W. (1996), "Impact of employment-related experiences on immigrants' psychological well-being and adaptation to Canada", Canadian Journal of Behavioural Science, Vol. 28 No. 3, pp. 240-251.

Berry, D.P. and Bell, M.P. (2011), “Expatriates' gender, race and class distinctions in international management", Gender, Work \& Organization, Vol. 19 No. 1, pp. 10-28.

Caligiuri, P. M. and Colakoglu, S. (2007), "A strategic contingency approach to expatriate assignment management”, Human Resource Management Journal, Vol. 17 No. 4, pp. 393-410.

Cerdin, J.L. and Selmer, J. (2014), "Who is a self-initiated expatriate? Towards conceptual clarity of a common notion", The International Journal of Human Resource Management, Vol. 25 No. 9, pp. 1281-1301. 
Cerdin, J.L., Dine M.A. and Brewster, C. (2014), “Qualified immigrants' success: Exploring the motivation to migrate and to integrate", Journal of International Business Studies, Vol. 45 No. 2, pp. 151-168.

Charmaz, K. (2006), Constructing Grounded Theory: A Practical Guide through Qualitative Research, Sage Publications, London.

Chiswick, B.R. and Miller, P.W. (2005), “Do enclaves matter in immigrant adjustment?”, City and Community, Vol. 4 No. 1, pp. 5-35.

Chua, A. and Rubenfeld, J. (2014), The Triple Package: How Three Unlikely Traits Explain the Rise and Fall of Cultural Groups in America, Penguin Press, New York, NY.

Dietz, J., Joshi, C., Esses, V. M., Hamilton, L. H. and Gabarrot, F. (2015), “The skill paradox: Explaining and reducing employment discrimination against skilled migrants", The International Journal of Human Resource Management, Vol. 26 No. 10, pp. 1318-1334.

Docquier, F., Marfouk, A., Salomone, S. and Sekkat, K. (2012), “Are skilled women more migratory than skilled men?", World Development, Vol. 40 No. 2, pp. 251-265.

Donato, K., Gabaccia, D., Holdaway, J., Manalansan, M. and Pessar, P. (2006), “A glass half full? Gender in migration studies”, International Migration Review, Vol. 40 No. 11, pp. 3-26.

Dorsch, M., Suutari, V. and Brewster, C. (2012), "Research in self-initiated expatriation: History and future directions", in Andresen, M., Al Ariss, A., Walther, M., and Wolff, K. (Eds.), SelfInitiated Expatriation: Mastering the Dynamics, Routledge: New York, NY, pp. 42-56.

Duckworth, A. (2016), Grit: The Power of Passion and Perseverance. Simon and Schuster, New York, NY.

Edmondson, A.C. and McManus, S.E. (2007), "Methodological fit in organizational field research”, Academy of Management Review, Vol. 32 No. 4, pp. 1155-1179.

Fang, T., Samnani, A.K., Novicevic, M.M. and Bing, M.N. (2013), "Liability of foreignness effects on job success of immigrant job seekers", Journal of World Business, Vol. 48 No. 1, pp. 98-109.

Fossland, T. (2012), "Highly skilled migration in the urban Arctic: A Norwegian case study on skilled migrant labour market integration", Polar Record, Vol. 48 No. 3, pp. 254-258.

Fossland, T. (2013), "Crossing borders - getting work: Skilled migrants' gendered labour market participation in Norway", Norsk Geografisk Tidsskrift, Vol. 67 No. 5, pp. 276-283.

Gaillard, J. and Gaillard, A.M. (1997), "Introduction: The international mobility of brains: Exodus or circulation?”, Science Technology \& Society, Vol. 2 No. 2, pp. 195-228. 
George, U. and Chaze, F. (2009), "Social capital employment: South Asian women's experiences", Affilia, Vol. 24 No. 4, pp. 394-405.

George, U., Chaze, F., Fuller-Thomson, E. and Brennenstuhl, S. (2012), "Underemployment and life satisfaction: A study of internationally trained engineers in Canada", Journal of Immigrant \& Refugee Studies, Vol. 10 No. 4, pp. 407-425.

Gephart, R. (2004), "From the editors: Qualitative research and the Academy of Management Journal", Academy of Management Journal, Vol. 47 No. 4, pp. 454-462.

Glaser, B. G. and Strauss, A.L. (1967), The Discovery of Grounded Theory: Strategies for Qualitative Research, Aldine Publishing, Chicago, IL.

Greenstone, M. and Looney, A. (2010), “Increasing productivity and boosting wages: Is innovation the answer?"; available at http://www.hamiltonproject.org/assets/legacy/files/downloads and links/07 jobs productivity.p df (accessed April 2017).

Guerrero, L. and Rothstein, M.G. (2012), “Antecedents of underemployment: Job search of skilled immigrants in Canada", Applied Psychology: An International Review, Vol. 61 No. 2, pp. 323-346.

Ho, C. (2006), "Migration as feminisation? Chinese women's experiences of work and family in Australia", Journal of Ethnic and Migration Studies, Vol. 32 No. 3, pp. 497-514.

Iredale, R. R. (2005), “Gender, immigration policies and accreditation: Valuing the skills of professional women migrants", Geoforum, Vol. 36 No. 2, pp. 155-166.

Jaccard, J. and Jacoby, J. (2010), Theory Construction and Model-Building Skills: A Practical Guide for Social Scientists, Guilford Press, New York, NY.

Johnson-Hanks, J. (2002), “On the limits of life stages in ethnography: Toward a theory of vital conjunctures", American Anthropologist, Vol. 104 No. 3, pp. 865-880.

Kaushal, N. and Fix, M. (2006), "The contributions of high-skilled immigrants", available at: http://www.migrationpolicy.org/research/contributions-high-skilled-immigrants (accessed April 2017).

Kerr, W. R. (2013), "U.S. high-skilled immigration, innovation, and entrepreneurship: Empirical approaches and evidence", available at: http://www.nber.org/papers/w19377 (accessed April 2017).

Killian, C. and Manohar, N.N. (2016), "Highly skilled immigrant women's labor market access: A comparison of Indians in the United States and North Africans in France", Social Currents, Vol. 3 No. 2, pp. 138-159. 
Kofman, E. and Raghuram, P. (2006), "Gender and global labour migrations: Incorporating skilled workers", Antipode, Vol. 38 No. 2, pp. 282-303.

Kolb, D. A. (1984), Experiential Learning: Experience as the Source of Learning and Development. Prentice-Hall, Englewood Cliffs, NJ.

Kolb, D. A., Boyatzis, R. E. and Mainemelis, C. (2000), "Experiential learning theory: Previous research and new directions", in Sternberg, R.J. and Zhang, L.F. (Eds.) Perspectives on Thinking, Learning, and Cognitive Styles, Lawrence Erlbaum, Mahwah, NJ, pp. 227-247.

Kvale, S. (1983), "The qualitative research interview: A phenomenological and a hermeneutical mode of understanding", Journal of Phenomenological Psychology, Vol. 14 No. 2, pp. 171-196.

Langley, A. (1999), "Strategies for theorizing from process data”, Academy of Management Review, Vol. 24 No. 4, pp. 691-710.

Lincoln, Y.S. and Guba, E.G., (1985), Naturalistic Inquiry (Vol. 75). Sage Publications, Beverly Hills, CA.

Liversage, A. (2009), "Vital conjunctures, shifting horizons: High-skilled female immigrants looking for work", Work, Employment \& Society, Vol. 23 No. 1, pp. 120-141.

Locke, K.D. (2001), Grounded Theory in Management Research, Sage Publications, London.

Lopez, M. J. (2012), "Skilled immigrant women in the US and the double earning penalty", Feminist Economics, Vol. 18 No. 1, pp. 99-134.

Mahroum, S. (2000), "Highly skilled globetrotters: Mapping the international migration of human capital", R\&D Management, Vol. 30 No. 1, pp. 23-32.

Man, G. (2004), “Gender, work and migration: Deskilling Chinese immigrant women in Canada”, Women's Studies International Forum, Vol. 27 No. 2, pp. 135-148.

Martin, P.Y. and Turner, B.A. (1986), "Grounded theory and organizational research", The Journal of Applied Behavioral Science, Vol. 22 No. 2, pp. 141-157.

Mattoo, A., Neagu, I.C. and Ozden, C. (2008), "Brain waste? Educated immigrants in the US labor market”, Journal of Development Economics, Vol. 87 No. 2, pp. 255-269.

Maxwell, J.A. (2004), "Casual explanation, qualitative research, and scientific inquiry in education", Educational Researcher, Vol. 33 No. 2, pp. 3-11.

McDonald, M.L. and Westphal, J.D. (2013), “Access denied: Low mentoring of women and minority first-time directors and its negative effects on appointments to additional boards", Academy of Management Journal, Vol. 56 No. 4, pp. 1169-1198. 
McNulty, Y. and Brewster, C. (2017), “Theorizing the meaning (s) of 'expatriate': Establishing boundary conditions for business expatriates", The International Journal of Human Resource Management, Vol. 28 No. 1, pp. 27-61.

Meares, C. (2010), “A fine balance: Women, work and skilled migration”, Women's Studies International Forum, Vol. 33, No. 5, pp. 473-481.

Miles, M. B. and Huberman, A.M. (1994), Qualitative Data Analysis: An Expanded Sourcebook (2nd edition), Sage Publications, Thousand Oaks, CA.

Muir, M., Wallace, M. and McMurray, D. (2014), "Women on the move: The self-initiated expatriate in China", Journal of Global Mobility, Vol. 2 No. 2, pp. 234-254.

Myers, B. and Pringle, J.K. (2005), "Self-initiated foreign experience as accelerated development: Influences of gender”, Journal of World Business, Vol. 40 No. 4, pp. 421-431.

Nager, A. B. and Atkinson, R.D. (2015), "Debunking the top ten arguments against high- skilled immigration", available at: http://www2.itif.org/2015-debunking-myths-high-skilled.pdf (accessed April 2017).

Osland, J., Kolb, D.A., Rubin, I.M. and Turner, M.E. (2007), Organizational Behavior: An Experimental Approach, Pearson Education: Upper Saddle River, NJ.

Patton, M. Q. (2005), Qualitative Research, John Wiley \& Sons, UK.

Pearson, J., Hammond, M., Heffernan, E. and Turner, T. (2012), "Careers and talents not to be wasted: Skilled immigrants' journeys through psychological states en route to satisfying employment", Journal of Management Development, Vol. 31 No. 2, pp. 102-115.

Piaget, J. (1977). The Development of Thought: Equilibration of Cognitive Structures. Viking, New York, NY.

Pillemer, D.B. (2001), "Momentous events and the life story", Review of General Psychology, Vol. 5 No. 2, pp. 123-134.

Przytuła, S. (2015), "Migrants, assigned expatriates (AE) and self-initiated expatriates (SIE)Differentiation of terms and literature-based research review", Journal of Intercultural Management, Vol. 7 No. 2, pp. 89-111.

Purkayastha, B. (2005), "Skilled migration and cumulative disadvantage: The case of highly qualified Asian Indian immigrant women in the US", Geoforum, Vol. 36 No. 2, pp. 181-196.

Ramboarison-Lalao, L., Al Arris, A. and Barth, I. (2012), "Careers of skilled migrants: Understanding the experiences of Malagasy physicians in France", Journal of Management Development, Vol. 31 No. 2, pp. 116-129. 
Ragins, B.R. and Kram, K.E. (2007), The Handbook of Mentoring at Work: Theory, Research, and Practice. Sage, Thousand Oaks, CA.

Ressia, S., Strachan, G. and Bailey, J. (2017), “Operationalizing intersectionality: An approach to uncovering the complexity of the migrant job search in Australia", Gender, Work \& Organization, Vol. 24 No. 4, pp. 376-397.

Salaff, J.W. and Greve, A. (2004), "Can women's social networks migrate?", Women's Studies International Forum, Vol. 27 No. 2, pp. 149-162.

Salaff, J. and Greve, A. (2003), "Gendered structural barriers to job attainment for skilled Chinese emigrants in Canada", International Journal of Population Geography, Vol. 9 No.6, pp. 443-456.

Schrauf, R.W. and Rubin, D.C. (2001), "Effects of voluntary immigration on the distribution of autobiographical memory over the lifespan", Applied Cognitive Psychology, Vol. 15 No .7, pp. S75-S88.

Shaffer, M.A., Kraimer, M. L., Chen, Y. and Bolino M.C. (2012), "Choices, challenges, and career consequences of global work experiences, a review and future agenda", Journal of Management, Vol. 38 No. 4, pp. 1282-1327.

Shachar, A. (2006), "Race for talent: Highly skilled migrants and competitive immigration regimes", New York University Law Review, Vol. 81, pp. 148-206.

Strauss, A. L. (1987), Qualitative Analysis for Social Scientists, Cambridge University Press, Cambridge, UK.

Strauss, A. and Corbin, J.M. (1997), Grounded Theory in Practice. Sage Publications, Thousand Oaks, CA.

Suddaby, R. (2006), "From the editors: What grounded theory is not", Academy of Management, Vol. 49 No. 4, pp. 633-642.

Suri, H. (2011), "Purposeful sampling in qualitative research synthesis", Qualitative Research Journal, Vol. 11 No. 2, pp. 63-75.

Suto, M. (2009), "Compromised careers: The occupational transition of immigration and resettlement”, Work, Vol. 32 No. 4, pp. 417-429.

Syed, J. (2008), "Employment prospects for skilled migrants: A relational perspective", Human Resource Management Review, Vol. 18 No.1, pp. 28-45.

Tharenou, P. (2010), "Women's self-initiated expatriation as a career option and its ethical issues", Journal of Business Ethics, Vol. 95 No. 1, pp.73-88. 
Tharenou, P. and Caulfield, N. (2010), "Will I stay or will I go? Explaining repatriation by selfinitiated expatriates", Academy of Management Journal, Vol. 53 No. 5, pp. 1009-1028.

Tharmaseelan, N., Inkson, K. and Carr, S.C. (2010), "Migration and career success: Testing a time-sequenced model", Career Development International, Vol. 15 No. 3, pp. 218-238.

van den Bergh, R. and Du Plessis, Y. (2012), "Highly skilled migrant women: A career development framework", Journal of Management Development, Vol. 31 No.2, pp. 142-158.

Weiss, H. M. (1990), "Learning theory and industrial and organizational psychology", in Dunnette, M.D. and Hough, L.M. (Eds.), Handbook of Industrial and Organizational Psychology (2nd edition), Consulting Psychologists Press: Palo Alto, CA, pp. 171-221

Winterheller, J. and Hirt, C. (2017), "Career patterns of young highly skilled migrants from Southeast Europe in Austria: Investigating accumulation and use of career capital", Personnel Review, Vol.46 No.2, pp. 222-236.

Yeoh, B.S.A. and Willis, K. (2005), "Singaporeans in China: Transnational women elites and the negotiation of gendered identities", Geoforum, Vol. 36 No. 2, pp. 211-222.

Zikic, J., Bonache, J. and Cerdin, J. (2010), "Crossing national boundaries: A typology of qualified immigrants' career orientations", Journal of Organizational Behavior, Vol. 31 No. 5, pp. 667-686.

Zong, J. and Batalova, J. (2016), "Frequently requested statistics on immigrants and immigration in the United States", available at: http://www.migrationpolicy.org/article/frequently-requestedstatistics-immigrants-and-immigration-united-states (accessed April 2017). 


\section{Table 1 - Coding Process, Data Structure, and Organization}

\begin{tabular}{|c|c|c|}
\hline $\begin{array}{l}\text { First-order concepts from open coding: } \\
\text { - Breaking data apart and delineating concepts } \\
\text { that stand for blocks of raw data } \\
\text { - Units of coding include paragraphs, sentences, } \\
\text { and words } \\
\text { - In vivo coding } \\
\text { - Multiple codes can be applied to any of the text }\end{array}$ & $\begin{array}{l}\text { Second-order categories } \\
\text { from axial coding: } \\
\text { - Interconnecting first- } \\
\text { order concepts } \\
\text { - Obtaining more } \\
\text { abstract second-order } \\
\text { categories }\end{array}$ & $\begin{array}{l}\text { Conceptual themes from } \\
\text { selective coding: } \\
\text { - Unifying categories } \\
\text { around central } \\
\text { phenomena } \\
\text { - Generating main } \\
\text { themes of the } \\
\text { phenomena } \\
\text { Delineating the } \\
\text { process model for the } \\
\text { phenomena }\end{array}$ \\
\hline $\begin{array}{l}\text { Multiple early gigs to gain work experience } \\
\text { Establishing early work history as a signal to } \\
\text { potential future employers } \\
\text { Low-paid jobs that provide learning opportunities } \\
\text { Voluntary jobs that build skills and contacts, future } \\
\text { references } \\
\text { Jobs one is overqualified for } \\
\text { Jobs unrelated to one's main occupation } \\
\text { Staying home to care of family }\end{array}$ & $\begin{array}{l}\text { Underemployment } \\
\text { Unemployment } \\
\text { Volunteer work } \\
\text { Domestic work }\end{array}$ & Non-linear career entry \\
\hline $\begin{array}{l}\text { Feelings of despair due to multiple rejections, } \\
\text { questioning self-worth and identity, lowered self- } \\
\text { esteem, and status collapse } \\
\text { Not working is not an option } \\
\text { Only being a 'mom' not acceptable } \\
\text { Career as a priority in life and for self-worth } \\
\text { Despite short breaks for child-bearing, work and } \\
\text { career takes precedence eventually - only after } \\
\text { proving themselves (to self), tendency to } \\
\text { intentionally lean back to maintain work-life } \\
\text { balance } \\
\text { The value and the need for work has been } \\
\text { conditioned since childhood } \\
\text { With valuable education and/or experience from } \\
\text { home country, putting that to good use is a major } \\
\text { motivation } \\
\text { Realizing career goals will not be realized } \\
\text { overnight but willingness to try and sacrifice }\end{array}$ & $\begin{array}{l}\text { Core self-identity } \\
\text { Life goals } \\
\text { Not wanting to be a } \\
\text { housewife } \\
\text { Wanting family and career }\end{array}$ & Career-orientation \\
\hline $\begin{array}{l}\text { Not giving up } \\
\text { Hard work and sacrifice } \\
\text { Trying alternative paths } \\
\text { Asking for opportunities, knocking on all doors } \\
\text { Awareness of shortcomings and liabilities that and } \\
\text { actively trying to overcome them } \\
\text { Pursuing some level of professional degree in the } \\
\text { U.S. to compensate for lack of local credentials. } \\
\text { Learning and growth orientation rather than } \\
\text { advancement up the hierarchy } \\
\text { After a big break, prove themselves quickly, gain } \\
\text { multiple promotions fast. } \\
\text { Positive reflection about career progress so far, but } \\
\text { motivated to still grow, learn, improve, and take on }\end{array}$ & $\begin{array}{l}\text { Grit } \\
\text { Impulse control } \\
\text { Patience } \\
\text { Persistence } \\
\text { Hard work } \\
\text { Growth-orientation }\end{array}$ & Immigrant spirit \\
\hline
\end{tabular}




\begin{tabular}{|c|c|c|}
\hline new challenges. & & \\
\hline $\begin{array}{l}\text { Most get the first 'real job' due to a Turkish } \\
\text { connection or through important, influential } \\
\text { contacts one had access to. } \\
\text { Spousal support if married - the most important } \\
\text { career enabler } \\
\text { Home country mentors residing in the U.S. } \\
\text { Host country mentors typically gained through } \\
\text { corporate programs somewhat helpful } \\
\text { Family here and back home support logistically, } \\
\text { psychologically, financially }\end{array}$ & $\begin{array}{l}\text { Helpful spouses } \\
\text { Resourceful extended } \\
\text { families } \\
\text { Access to influential } \\
\text { contacts }\end{array}$ & Social support network \\
\hline $\begin{array}{l}\text { Socialization is a challenge at work due to lack of } \\
\text { cultural frame of reference and cultural differences } \\
\text { Social contexts at first difficult due to these } \\
\text { differences, having an accent or language barriers } \\
\text { Easier to socialize and find work friends when } \\
\text { young and single, later becomes more difficult } \\
\text { though it depends on company culture } \\
\text { Typically, more socialization with similar others } \\
\text { (i.e. minorities or Turks) or no socialization beyond } \\
\text { the water cooler } \\
\text { Some perceive being an immigrant as a positive for } \\
\text { socialization such as others paying more attention } \\
\text { or as a conversation starter/ice breaker, people } \\
\text { remembering you because of your name, or your } \\
\text { accent, or communication being more measured } \\
\text { Glass ceiling perceived as less of an immigrant } \\
\text { issue and mostly a gender issue. None felt } \\
\text { intentionally discriminated against due to their } \\
\text { national-origin in career-related opportunities. } \\
\text { Main barrier to getting in the old boys' club was } \\
\text { lack of similarity and lack of shared interests }\end{array}$ & $\begin{array}{l}\text { Cultural adaptation } \\
\text { Building social connections } \\
\text { Learning to fit in } \\
\text { Gender-based glass ceiling }\end{array}$ & $\begin{array}{c}\text { Socialization patterns at } \\
\text { work }\end{array}$ \\
\hline
\end{tabular}


Table 2 - An Experiential Learning Model of Career Reconstruction among High-skilled Female Immigrants*

\begin{tabular}{|l|l|}
\hline Theoretical Propositions & Conceptual Themes and Learning Stages \\
\hline $\begin{array}{l}\text { Proposition 1: High-skilled immigrants with higher } \\
\text { levels of career-orientation are more likely to set the } \\
\text { learning cycle in motion and immerse themselves in } \\
\text { concrete experiences in job search and career-building. }\end{array}$ & $\begin{array}{l}\text { Learning stage: All stages } \\
\text { Conceptual theme: Career-orientation }\end{array}$ \\
\hline $\begin{array}{l}\text { Proposition 2: Early career-related concrete } \\
\text { experiences of high-skilled immigrants are } \\
\text { characterized by a non-linear path and periods of } \\
\text { excessive job search, unemployment and } \\
\text { underemployment. }\end{array}$ & $\begin{array}{l}\text { Learning stage: Concrete experience } \\
\text { Conceptual theme: Non-linear career entry }\end{array}$ \\
\hline $\begin{array}{l}\text { Proposition 3: High-skilled immigrants that keep on } \\
\text { turning the learning cycle display immigrant spirit } \\
\text { qualities such as grit (Duckworth, 2016) and impulse } \\
\text { control (Chua and Rubenfield, 2014). }\end{array}$ & $\begin{array}{l}\text { Learning stage: All stages } \\
\text { Conceptual theme: Immigrant spirit }\end{array}$ \\
\hline $\begin{array}{l}\text { Proposition 4: High-skilled immigrants who objectively } \\
\text { and intentionally try to understand concrete experiences } \\
\text { drive lessons learned that they use for active } \\
\text { experimentation. }\end{array}$ & $\begin{array}{l}\text { Learning stage: Reflective observation, } \\
\text { active experimentation } \\
\text { Conceptual theme: NA }\end{array}$ \\
\hline $\begin{array}{l}\text { Proposition 5: High-skilled immigrants that eventually } \\
\text { become successful actively and creatively experiment } \\
\text { with different tactics to overcome barriers and } \\
\text { shortcomings. }\end{array}$ & $\begin{array}{l}\text { Learning stage: Active experimentation } \\
\text { Conceptual theme: NA }\end{array}$ \\
\hline $\begin{array}{l}\text { Proposition 6: High-skilled immigrants' social support } \\
\text { network and connections gain prominence during the } \\
\text { active experimentation stage in the learning cycle. }\end{array}$ & $\begin{array}{l}\text { Learning stage: Active experimentation } \\
\text { Conceptual theme: Social support network }\end{array}$ \\
\hline $\begin{array}{l}\text { Proposition 7: Learning cycle of high-skilled } \\
\text { immigrants' post-career entry emphasize understanding } \\
\text { and learning socialization patterns in the workplace. }\end{array}$ & Learning stage: Recurring cycle \\
& \\
\hline
\end{tabular}


Birth Year:

\section{PART I: Preliminary Information}

Marital Status:

Number of Children:

Higher Education Completed in Turkey (University/major/graduation date):

Work experience, if any, in Turkey (years/industry):

Year moved to the U.S.:

Reason for relocating to the U.S.:

Other, if any, countries of residence/length/year moved:

Current job:

Current organization:

Years at current job/organization:

Other, if any, work experiences in the US (volunteer and paid employment):

Education, if any, in the U.S.:

\section{PART II: At the time of immigration}

1. Can you tell me about your initial experience when you first moved to the US? What kind of an experience was it?

2. When and why did you decide to enter the workforce?

a. What kind of alternatives did you consider and research during this process?

3. How did you conduct your job search?

a. What kind of difficulties did you encounter during your job search?

b. How did you manage the challenges you encountered during your job search?

c. Can you share with us any positive or negative experiences you had during your job search?

4. What kind of characteristics do you think helped you find a job?

a. How do you think being a foreigner affected your job search? Positive or negative? Can you explain?

5. Can you tell me about your current job?

\section{Part III: About your career}

a. What do you find satisfactory or unsatisfactory about your current job?

b. What are your biggest challenges in the work domain?

c. How do you deal with these challenges?

6. Are there any areas you feel incompetent or less prepared in your current position? Can you explain?

7. Can you tell me about your relationships with your co-workers in the workplace?

a. Do you socialize with your co-workers? Who are they? How often do you socialize? What do you do for socialization?

b. Do you have very good friends or a best friend at work? Can you explain?

8. Do you feel 'being a foreigner' in your current workplace? When do you feel it the most?

a. Are there any advantages to being a foreigner in your career?

9. How you feel about your career advancement in the US so far?

a. What kind of benefits do you think the work experience in the US provided you with?

b. What are the most stressful topics at work for you?

10. How satisfied are you with your current career achievement? Can you explain?

11. Are there any people (professional or private) who (directly or indirectly) helped you achieve your career goals? How did they help you?

12. Can you tell me if you feel the existence of glass ceiling as a career woman? Can you explain?

a. Do you think there is a glass ceiling for foreigners? Can you explain?

\section{Part IV: Future plans}

13. Do you plan to return to Turkey? Under what conditions would you consider going back?

a. Would you consider moving to a different country?

14. What are your future career goals, objectives and dreams?

15. Are there any cultural differences in the workplace between Turkey and the US?

16. Is there anything you want to add? 